\title{
Legal framework to protect the interest of the Domestic Workers in Sri Lanka: An analysis in the light of International Instruments
}

\author{
M.M.R.M.Neththipola Dissanayake \\ Attorney-at -Law, Lecturer in Law, Department of Management \\ Advanced Technological Institute- Kururnegala \\ Sri Lanka Institute of Advanced Technological Education-Sri Lanka \\ neththipola@gmail.com \\ DOI: 10.29322/IJSRP.11.06.2021.p11436 \\ http://dx.doi.org/10.29322/IJSRP.11.06.2021.p11436
}

\begin{abstract}
This paper endeavors to critically evaluate the legal provisions which available to protect the interest of the Domestic Workers in Sri Lanka in the light of international instruments and it attempts to reaffirm the inadequacy of the existing legal system for domestic workers. It investigates whether and in to what extent the existing legal provisions are able to protect the interest of the Domestic Workers and in which areas in the Sri Lankan legal framework needs to be reformed in order to bring Sri Lankan law in line with the international legal standards and in to what extent. Also, this study attempts to identify the new areas to develop an effective legal regime for the domestic workers to avoid the existing barriers and match with the international standards.
\end{abstract}

Index Terms: contract of employment, domestic workers, minimum wages, personal security, safe working environment, working hours

\section{Introduction}

Domestic Sector is one of the main sectors of employment in Sri Lanka and recently there may be rapid demand for domestic workers in the country. It is very important to formulate better employer employee relationship in the domestic sector because the domestic worker plays a significant role in employers' life by working in employer's own house. In Sri Lankan context house must be the most comfortable, peaceful and pleasant, place for every person. Therefore, not only the better relationship between the family members but also the relationship with the domestic employees can affect for the peaceful domestic environment. As Mr. A Saraveswaran pointed out in his research paper ${ }^{1}$ by using the phrase 'work like any other, work like no other' which was taken from the ILO Report on Domestic Workers, the domestic workers extended significant service to the society as the other service providers, but they have no legal safe guard and recognition as the employees of the other sectors.

Presently there are few of legal provisions available to protect the rights of the domestic employees. Registration of Domestic Servants Ordinance No 28 of 1871 and Chauffeurs Ordinance 1912 were the only pieces of legislations

\footnotetext{
1 Domestic Workers' Rights in Sri Lanka - Work Like Any Other, Work Like No Other: Need for a Legislative Intervention -Annual Research Symposium 2012 -University of Colombo 141--143
} 
directly address the rights of the domestic workers. But those Ordinances are not presently in operation. In the present legal context, some provisions in Industrial Disputes Act is apply for the domestic employees. Therefore, no argument that there is a higher need of a separate legislation for the domestic workers in Sri Lanka. Because when we discuss about the domestic workers rights it is closely connected with women's rights which ensure under the Convention on Elimination of all forms of Discrimination against Women (CEDAW) and the rights ensure under the Unites nations International Covenant for Civil and Political Rights (UNICCPR). Even though Sri Lanka is a member country for the above international instruments the Sri Lankan government has not yet ratified the Decent Work for Domestic Workers Convention No.189 which composed with an effective legal provision to ensure the interest of the domestic workers in different related areas. The objective of this research is to discuss the gravity of the above vacuum of the law and to propose suitable recommendations to fill that gap.

\section{Research Methodology}

The main objective of this research project was to analyses whether the existing legal regime to protect the rights of the domestic workers in Sri Lanka are adequate to protect the rights of the domestic workers. In order to fulfil this main objective, firstly the legal framework which available to protect the rights of the domestic workers has examined. Secondly, an evaluation of the existing national and international legal provisions was done in order to raise the short comings of the existing provisions. Thirdly, this paper identified the loopholes of the existing legal framework. Finally, necessary amendments to the existing legal provisions and appropriate new developments to enhance the interest of the domestic workers were suggested. Furthermore, comparative legal research and analysis on the international instrument have been conducted in order to ascertain international perspectives on domestic workers.

This is a normative research; therefore, the above objectives have achieved by means of a literature review 'desk research' and unstructured interviews with the officials who were engaged in work with the related government authorities and non-governmental organizations.

On a random basis, twenty-five female domestic workers who live in Kurunegala District who are between 40 and 65 years of age, will be selected and interviewed, by requesting them to verbally answer to a questioner composed by me. Further, an unstructured interview will be conducted with 10 male domestic workers of the above District to obtain their opinion on relevant matters. This survey focuses mainly on working hours, remuneration, contract of employment, working environment, weekly holiday and maternity benefits. The findings of the surveys and the results of the interviews were mostly used to make new suggestions and recommendations.

When design this research paper it limits for three main components related to the domestic workers. Firstly, the paper will discuss the general provisions for domestic workers. In that discussion the researcher will work with the way of define the domestic worker and the nature of the present contract of employment, probation period, the provisions of payment of wages and weekly holidays. Also, under the above component the researcher attempts to discuss about the termination of employment, registration of employees, human rights and right to organize. Secondly the paper will discuss about the women domestic workers paying special attention to maternity benefits and sexual harassment. Thirdly the paper will discuss about the child domestic workers highlighting the provisions for minimum age and the child labour.

\section{Results and findings}

This publication is licensed under Creative Commons Attribution CC BY.

http://dx.doi.org/10.29322/IJSRP.11.06.2021.p11436

WwW.ijsrp.org 
After examine the field of domestic workers in Sri Lanka, four areas were identified to make proposals to amend the existing legal framework. Namely, the weaknesses of the existing legislation, practical barriers to the enforcement of the laws relating to domestic workers, uncertainties and discrepancies within the existing legal framework, new suggestions and recommendations in keeping with the international standards which are not yet ratified by the Sri Lankan Government.

\section{General Provisions}

\subsection{Definition of a Domestic Worker}

None of the Sri Lankan legislations provided the definition for the domestic workers. The countries like Viet Nam, Barbados, provided definitions in their legislations. Section 139 of Viet Nam Labour Code defines as 'a persons who are employed to help in households.' The Domestic employee Act of Barbados defines as any person employed for reward for the performing household duties in a private dwelling ${ }^{2}$. Article 01 of the ILO Convention ${ }^{3}$ provided very broad definition for the domestic work and for the domestic worker. According to this definition domestic worker is the person who engages domestic work within an employment relationship.

The researcher proposed to have separate piece of legislation for the domestic workers in line with international standards. Because they are not recognized or covered under any labour legislation available in Sri Lanka except Industrial Deputes Act. This paper strictly recommends to ratified Convention 189 and adopted that definition and provisions for a separate legislation.

\subsection{Contract of employment}

The contract of employment must be in written format with necessary terms and conditions. Most probably the nature of the contract between the domestic worker and the employer seems to be verbal. In my survey I exposed that some employers try to interpret the domestic worker as an independent contractor. The Shop and office employees Act emphasize the requirement of the written contract of employment. But unfortunately, the said Act is not covered the domestic workers. But if there is a written employment contract it can considers as an important mechanism to demand to the worker and affirm to the existence of an employment relationship and its terms. In United States written contract is required to the employees placed by the agencies. ${ }^{4}$ In South Africa requires to an employer to supply a detailed, written list of particulars to domestic workers when they start work. ${ }^{5}$

Therefore, there are two alternatives to rectify this situation there must be either amending the existing legislation which emphasize requirement of written contract to cover the domestic workers or must be formulate separate Act. Article 6 and 7 of the ILO Convention C.189 promoted a written contract and Article 6 of the above convention very clearly mentioned the requirements which should include in the contract. Therefore, if the government ratify the above convention it is easy to develop separate piece of legislation effectively by using the above provisions as guidelines.

\subsection{Probation Period}

\footnotetext{
2 International Labour Conference 99^ Session 2010, Report (iv) i, Decent Work for domestic workers, International Labour Office Geneva. para 109

3 Decent Work for Domestic Workers Convention No.189 (2011)

${ }^{4}$ International Labour Conference $99^{\text {th }}$ Session 2010, Report (iv) i, Decent Work for domestic workers, International Labour Office Geneva. para 126

${ }^{5}$ Section 9(1) of Sartorial Determination 7, South Africa
} 
Employer should clearly mention the period of probation in the employment contract. This is a trial period and in this period the employer could terminate the employee without giving any reason if he does not come up to the expectations to the employer. ${ }^{6}$ In Sri Lanka most of the public and private sector organizations imposed a probation period. But still it is not applying for the domestic workers. In the domestic sector parties should have free consent to decide whether they continue the job or terminate. But in this sector only the employer could enjoy the decision-making power. Unlike the other sectors in this case the workplace is employers own house therefore if the employee's behaviors and attitudes are not match with the employer better to have chance to discontinue the employment without having a person with an unpleasant mind. According to Section 77(7) of Colombian Labour Code the probation period is 15 days, According to Italian National Collective agreement and under the Viet Nam Labour Code it is maximum 30 days. National Collective agreement in France, Section 08 also provides it is as 30 days.

In Sri Lanka the employees of the government and semi government sector have to complete three years as probation period and the private sector it can be one year, six months or sometimes 03 months. Therefore, the researcher highly recommends a separate Act with the specified period of probation because the nature of this service cannot compare with other sectors. According to the abovementioned international examples the number of days must be less than the other sectors.

\subsection{Remuneration/Wages/Salary}

There should be clear provisions regarding the payment of wages, amount of wages, minimum wage rate because there is no any other provision under the existing labour Acts for the above purpose. In the survey done by the researcher it was found out that there is no specific date to payment of wages sometimes employers use to accumulate the salary and pay after few months without any interest or additional payment.

In Sri Lanka Wages Boards Ordinance is the main legislation which provides legal provisions on payment of wages. But domestic workers are not covered the Wages Boards Ordinance.

Minimum wage provisions are important instruments to protect the vulnerable and lowest paid workers from unduly low wages. ${ }^{7}$ There should be a minimum wage rate to all the categories of domestic employees. In the year 1975 Sri Lanka has ratified the Minimum Wage Fixing Convection 1970 (C.131). Article 1 of the above convention provided that 'each member of the International labour organization which ratifies this Convention undertake to establish a system of minimum wage which covers all the groups of wage earners whose terms of employment are such that coverage'. Therefore, after passing 46 years still Sri Lanka did not consider the domestic workers as wage earners. At least the domestic workers are not covered by the National Minimum Wage of Workers Act No 3 of 2016. In the year 2002 South Africa has introduced minimum wages provisions for their domestic workers. In Asia Philippines and Viet Nam covered by the minimum wage legislations. Comparatively Sri Lankan legal system on the domestic workers was developed at a snail phase.

The Article 11 of the ILO Convention (C.189) has provided that the member governments should ensure the minimum wage limits and it further stated that it should apply without sex discrimination. This paper strongly recommends to enact new laws rather than expansion of the existing laws by using the provisions of the ILO Conventions as guidelines.

\footnotetext{
${ }^{6}$ Richard Pieris \& Co. Vs.Jayathunga,Sri Kantha Law Reports, Vol 1 P.17

${ }^{7}$ Preamble ILO Minimum Wage Fixing Convention 1970 ( No C. 131)
} 


\subsection{Working Hours}

In Sri Lanka all the other sectors of employments have specific working hours and if a certain employee exceeds that prescribed hours employer have pay overtime payments for the additional hours. The Shop and office Employees Act provided 45 hours per week and the Wages Boards Ordinance provided it as 48 hours per week. But the domestic employees are not covered by any of the above Acts. Therefore, no specific time for work and the workers live in, the employer expected to be available at all times. This situation is unfair and there should be a limited number of hours for them to work and also to rest.

Employment of Woman Young Persons and Children's Act restricted night work for the women employees. But in Sri Lanka none of the above Acts protected the domestic employees.

Article 10 of the ILO Convention C. 189 mentioned that the member countries have to equally treat to the domestic workers and workers generally in relation to normal hours of work, over time and compensation. But this equal treatment has not practice with the domestic workers by any employers. The researcher does not recommend the amendments for the existing Acts because of the specific nature of the service of the domestic workers there must be separate legislation with suitable to their pattern of employment. Hence this paper proposes to ratify the ILO Convention C.189 to pave the path to enact domestic laws accordingly.

\subsection{Weekly Holiday}

In each week the domestic employees need to have a weekly holiday even for a single day for a week. Wages Boards Ordinance provides one day and the Shop \& Office Employees Act provides one and half day as weekly holiday but the above Acts are not covered the domestic employees. Because unlike other employees domestic workers are work in houses so if they refresh their physical and mental condition which involve with extra activities, religious, family commitments, they may give the service fresh and pleasant mood, it will be a pleasant experience for the house holders and the kids staying with the worker. ${ }^{8}$ That means by providing weekly holidays it will cause to give effective service reducing mental depress, unhappiness, fed up with works and negligence.

Weekly Rest (Industry) Convention of 1921 No 14 and Weekly Rest (Commerce and office) Convention of 1937 No 106 provides that there should be a single day off per week. Article 10 of the ILO Convention No 189 has also provided 24 hours rest should be given to the domestic worker per week. Further it clearly stated that the member countries should provide annual leave and weekly holidays similarly to the other employees in the country.

According the data gathered from the survey and the interview most of the domestic workers obtained few days as monthly holidays. They don't have any idea about weekly holiday. Hence domestic workers have discriminated among the other employees because there is no any single hour recommended under any domestic law. And still Sri Lankan government did not take steps to ratify the ILO Convention 189 which could strengthen the Domestic law.

The researcher strongly recommended that there must be not only the amendments needed but also there must be development the operational level.

8. Preamble ILO Minimum Wage Fixing Convention 1970 ( No131) 


\subsection{Safe and healthy working environment}

In Sri Lanka while the Factories Ordinance ensure health, safety and welfare for the employees who works in factories the Shop and Office Employees Act provided health and safety provisions for the employees who are working in shops and offices, the domestic workers are not covered by the above legislations.

But they are the people who strongly need the legal protection in such legislations. Because they are not living with their own family members therefore, they need to have much safe accommodation, health facilities and sanitary facilities. This area is not covered under any legislation. But employer should have the responsibility to make necessary arrangement to avoid the hazardous situations.

Further the Article 5 of the ILO Convention provided that the employer should provide good working environment for the domestic employee which enables to ensure the right to privacy. Also, the Article 13 of the above said convention mentioned the governments' needs to take necessary steps to ensure safe and healthy working environment for the domestic workers. In South Africa labour Inspectors can visit private households to inspect the working environment and sanitary facilities of the workers ${ }^{9}$. Hence Sri Lanka need the legal reforms in Acts and the operational mechanisms as well.

\subsection{Registration of Domestic Workers and Agencies}

Under the Registration of Domestic Servants Ordinance, No 28 of 1871 the domestic workers have to be registered in the police station. But presently these provisions are not in operation. Currently there are several informal agencies to provide domestic workers and there is no provision to register the employment agencies. These agencies also should come under the control, investigation and monitoring of the Department of Labour.

The ILO Convention C. 189 provided the similar provisions in Article 16 in a broad manner and stated the agencies should registered by the government and the states should monitor the activities of the above agencies.

The researcher strongly recommended to establish separate mechanism either in the district secretariat level or connected with district labour office for the monitoring and inspection of the registration process and to conduct random visit. It is a practical requirement which enable establish a comfortable environment for the workers.

\subsection{Protection of Human rights and right to organize}

As human beings' domestic workers also should have rights to live with human dignity. Still there is no specific local or international legislation to cover this area. But Article 3 of the ILO Convention (C.189) provided clear legal background regarding protection of human rights. Also, this Article emphasized the freedom of association and right to collective bargaining. Article 3 of the Freedom of Association and Protection of the Right to Organize Convention 1948 No 87 has provided that the employee or employer of any category can enjoy the freedom of Association and right to organize. Consequently, the Domestic Workers Union has established on 2012 with the intention of protect the demanding and the bargaining rights of the domestic workers. Even though that mechanism is available it also seems cannot achieve the expected goals due to the legal barriers and vacuums in the country.

\footnotetext{
${ }^{9}$ Sri Lanka Domestic Workers an Analysis of the legal and policy frame work, Decent Work for Domestic Workers Report No.1 Verit'e Research (2015) p.30
}

This publication is licensed under Creative Commons Attribution CC BY.

http://dx.doi.org/10.29322/IJSRP.11.06.2021.p11436

WwW.ijsrp.org 
Therefore, the researcher highly recommended to formulate the separate legal provisions to strengthening the above rights.

\section{Women Domestic Workers}

According to $\mathrm{Mr}$ A. Saraveswaran most of the domestic workers are females and children, and they are subject to forced labour, sexual abuse and harassment. ${ }^{10}$ That means women and child domestic workers are most vulnerable so they need strong legal protection to minimize the above threats.

\subsection{Maternity Benefits}

According to the labour force survey conducted in 2007 it was recorded that there was a total of 87,400 domestic workers in the country and 60,400 of whom were females. ${ }^{11}$ Therefore in addition to the above situations have to pay special concern about the maternity benefits and leave. Because the domestic workers are the category of employees who are not covered under any Statutes for Maternity Benefits. The Shop and Office Employees Act and The Maternity Benefits Ordinance are the statutes which applies for the maternity benefits. The previous Act is not applied for the domestic workers and the former Act expressly excludes them. There are 84 working days leave for the Shop and Office employees and 84 days leave for the employees who work in trades can enjoyed as maternity leave.

The ILO convention C.189 provided certain provisions but it didn't mention specific numbers of dates. But Maternity Protection Convention 1952 C.103 ratified by the Sri Lankan government and it includes 'domestic workers for wage' as well. But still the domestic laws are not amended according to international standards. In most of the foreign countries accepted the above 84 days period as maternity leave for the domestic employees.

This situation generates discrimination not only among the domestic workers and the other workers but also among the children of the domestic workers and the children of other workers. Hence there is a situation where indirectly violation of Child rights. In my survey I found that three domestic workers who have small kids under one year, suffered a lot by missing their child. But they continue their service because they have no job security.

Therefore, this paper strongly proposed the requirement of a specific Act which contain the maternity leave and benefits to the domestic worker to avoid this discrimination.

\subsection{Sexual Harassment}

The provisions should include preventing for all types of sexual harassments. Because in the domestic sector these harassments are common and easy to occur and in most of the cases the victims are not in a

\footnotetext{
10 Domestic Workers' Rights in Sri Lanka - Work Like Any Other, Work Like No Other: Need for a Legislative Intervention -Annual Research Symposium 2012 -University of Colombo 141--143

11 Verit'e Research (2015) Sri Lanka Domestic Workers. An Analysis of the legal and policy framework. Decent Work for Domestic Workers Report No.1 P.30
} 
position to complain the harassments. According to the findings of my survey 5\% of the domestic workers stated that they face some harassments but they afraid to make complains because they need to continue their job.

The ILO Convection 189 provided in its Article 8 that the governments should take measures to ensure that the domestic employees are enjoy protection against all types of abuses and harassments. But none of the existing domestic laws are covered this area, hence the researcher strongly recommends to create a separate act to cover all the female employees in each sector.

\section{Mechanism for settling disputes}

Further there should be a specific mechanism formulated to investigate, settle and prevent the matters regarding the domestic workers. The Labour Tribunal has filled this gap in some extent but it not a sufficient and suitable mechanism to address the above matters. Therefore, there should be a mechanism to complain about abuse, physical, verbal, sexual, mental harassments even the unlawful confinement. ${ }^{12}$ Article 14 of the ILO Convention 189 provided that domestic employees should have right to access to any court or Tribunal by themselves or by representatives. This can be practical if an easy access tribunal are available in the country.

\section{Child Domestic Workers}

\subsection{Minimum Age for child domestic workers}

Employment of Women, Young Persons and Children Act No 47 of 1956 defines the person under 14 years as a child, and the State Indian Labour Ordinance provided the same. Shop and Office Employees Act also provided it as 14 years.

But when concern the current international standard for this instance, the best example is the Article 4 of the ILO Convention 2011 on Domestic Workers. It provides the minimum age as 18 years. The article 03 of the Minimum Age Convention No 138 also provided the similar provisions. Therefore, in near future this age limit will apply for the member countries. Eventually it is meaningless that we developing provisions for the child domestic workers without concerning the minimum age requirement. Because this provision could protect the other important rights as right to education, vocational training, even the right to childhood. But still in the developing countries there is no prohibition to engage work for children over 14 years of age with some restrictions. Most of them use to work as child domestic workers because lack of the skills and experience they cannot find other jobs. Therefore, engage the researcher proposed special legal provisions to protect the interest of the child domestic workers.

\subsection{Working hours for child domestic workers}

The researcher proposed there should be maximum house of work for the child domestic workers because long working hours can give chance for abuse and exploitations. There are some provisions coming under the Employment of Women, Young Persons and Children Act No 47 Of 1956 Act. But the researcher emphasized that there must be prohibition on work during early and late hours and the provisions should develop to ensure rights to adequate time to rest, training, education, homework and to enjoy the childhood. ILO Convention No 182 provides a proper guidance regarding the above matter.

\footnotetext{
12 ILO Domestic Law Policy Brief 5
} 


\section{Conclusion}

In conclusion, researcher intends to explain the present situation of the legal regime regarding the domestic workers. Further to brief the proposals made with the findings and finally to make suggestions to develop the future of the above legal background. Sri Lankan Government and the policy makers still in the same destination where the country was before 10 years ago. In the year 2011 internationally recognized the rights and interests of the domestic workers by the Convention $189^{13}$. Then in the year 2012 there were discussions and inspirations to ratify the above convention. Mr A. Saraveswaran in his research paper on Domestic workers ${ }^{14}$ made an effort to give recognition for the domestic workers but it was not continuing further. In 2015 Ms.Sabrina Esufally with a legal research team prepared their report No 01, ${ }^{15}$ after conducted a research on Sri Lankan domestic workers. This report had identified important benchmarks and broadly discussed that areas. It was a significant study and further it was a real answer to the question why the policy makers need to ensure the rights and interest of the domestic workers. In the year 2019 there was another research done by The Centre for Women's Research (CENWOR) with the objective of assist the government to ratify Convention 189 and include it to the National Human Rights Action Plan 2017$2022^{16}$. But still the legal background of the domestic workers was remaining without any changes or new trends.

Hence the researcher concern two alternatives as a solution for the above situation. Firstly, concern that whether the legal provisions could be developed by expansion and amendments of the existing laws and secondly to enact new laws specifically for the domestic workers. In this research paper the researcher again and again confirms the inadequacy of the existing legal provisions and further it emphasizes the ineffectiveness of the emending of the existing legal regime. Because the existing legislations have covered and established for the employees of the other sectors, which have different nature of working hours, weekly holidays and the working environment. The researcher strongly rejected the first view of expansion of the existing laws. This paper strongly recommends to enact new laws rather than expansion of the existing laws.

When draws attention to the second aspect again there were another two streams come across as whether firstly Sri Lanka need to ratify the ILO Convention 189 or whether the parliament enact new legislations to protect the interest of domestic employees. For this instance, researcher strongly recommend to ratify the ILO Convention as a first step to clear the path to develop new legal regime. Because the researcher very clearly found that there were heavy social, cultural, economic, and psychological barriers to develop this area of law. Hence the researcher highly believes that ratification of ILO Convention 189 creates a strong foundation and provided guideline to enact new legislations to protect the rights and interest of the domestic workers. But the success of this procedure will totally depends on the government policy and the effectiveness of the advocacy campaigns of the groups who work in this regard.

\footnotetext{
13 Decent Work for Domestic Workers Convention No.189 (2011)

${ }^{14}$ Domestic Workers' Rights in Sri Lanka - Work Like Any Other, Work Like No Other: Need for a Legislative Intervention -Annual Research Symposium 2012 -University of Colombo 141--143

${ }^{15}$ Verit'e Research (2015) Sri Lanka Domestic Workers. An Analysis of the legal and policy framework. Decent Work for Domestic Workers Report No.1

${ }^{16}$ Ratifying Convention 189, Formalizing domestic work in Sri Lanka By Awanti Arscularatne,Daily News, $11^{\text {th }}$ February, 2020
} 


\section{Bibliography}

1. Domestic Workers' Rights in Sri Lanka - Work Like Any Other, Work Like No Other: Need for a Legislative Intervention -Annual Research Symposium 2012 -University of Colombo 141-143

2. International Labour Conference $99^{\text {th }}$ Session 2010, Report (iv) i, Decent Work for domestic workers, International Labour Office Geneva.

3. Decent Work for Domestic Workers Convention No.189 (2011)

4. Section 9(1) of Sartorial Determination 7, South Africa

5. Richard Pieris \& Co. Vs.Jayathunga,Sri Kantha Law Reports, Vol 1

6. Preamble ILO Minimum Wage Fixing Convention 1970 ( No131)

7. Sri Lanka Domestic Workers an Analysis of the legal and policy frame work, Decent Work for Domestic Workers Report No.1 Verit'e Research (2015)

8. ILO Domestic Law Policy Brief 5

9. Verit'e Research (2015) Sri Lanka Domestic Workers. An Analysis of the legal and policy framework. Decent Work for Domestic Workers Report No.1

10. Ratifying Convention 189, Formalizing domestic work in Sri Lanka. By Awanti Arscularatne, Daily News,11 $11^{\text {th }}$ February 2020

11. Shop and Office Employees Act

12. Wages Boards Ordinance

13. Employment of Women, Young Persons and Children Act No 47 0f 1956 Act.

14. Minimum Age Convention No 138 of 1973

15. Registration of Domestic Servants Ordinance No 28 of 1871 and No 18 of 1936

16. Industrial Disputes Act No 43 of 1950

17. Maternity Benefits Ordinance

18. ILO Convention No 182

19. Freedom of Association and Protection of Right to Organize Convention 1948

20. Weekly Rest (Industry) Convention of 1921 No 14 and Weekly Rest (Commerce and office) Convention of 1937 No 106

21. National Minimum Wage of Workers Act No 3 of 2016.

22. Chauffeurs Ordinance 1912

23. Labour Code 